\title{
腐食防食のためのデータベースシステム
}

\author{
佐々木英 次* \\ * 化学技術研究所
}

\section{Database Systems for Corrosion Engineering}

\section{Hidetsugu Sasaki*}

* National Chemical Laboratory for Industry

\begin{abstract}
The cost of corrosion is estimated to be a few percent of the Gross National Product, and considerable extent of which could be saved by using existing technology. Corrosion database systems help utilizing exisiting data and thus contribute to the realization of these cost savings. Forefront of factual databases and expert systems was reviewed. It is expected that better factual databases and good algorithmes must be complied. Knowledge based systems integrated with other application software are very promising.
\end{abstract}

Key words: corrosion database, factual database, expert systems

\section{1.はじめに}

脱工業化社会が言われて久しい。情報技術の進歩は目 を見張るものがある。しかし，その脱工業化社会も各種 材料から構成される機器, 構造物, 施設等社会資本の維 持管理が出来なければ成立しない。昭和，51 年に行われ た腐食損失に関する調査 ${ }^{11}$ によると, 我が国に括ける腐 食損失額は年間, GNP の 1 2\% (昭和 49 年基準で 1 兆 400 億円 2 兆 6000 億円) と見積もられている。昭 和 61 年に出された資源調查所「錆対策研究会」の報告2) でも，その対策として「腐食防食センター」を設置し， 重要任務として, 腐食防食知識の普及が挙げられている。 さらに米国では NBS が議会に提出した同種の報告3)の 中で, 計量経済学の手法を用いた経済分析を行ってお り，1975 年ベースで GNP の 4.2\% に当たる 700 億ド ルの損失があり，その内 $15 \%$ に当たる 100 億ドルは現 用技術の知識の普及で防ぐことがでさるとしている。そ して NACE-NBS の Corrosion Data Program では, 防食知識の普及を目指してデータベースの構築を始めて いる。

腐食防食の研究成果は単に原理が理解できたり, 方法 が開発されたことだけに止まるのではなく，社会に広く 普及してこそ意義を持つ。そのためには発展著しい情報

* 干305 茨城県つくば市東 1-1 (1-1, Higashi, Tsuku ba, Ibaraki, 305 Japan)
技術の利用は必須である。特に人工知能 (AI) 技術の一 つとして実用化されつつあるエキスパートシステムはま ず医療や教育分野で実現しそらである。防食技術がしば しば医療と例兄られるように, 腐食診断とその対策, 材 料選択等にはすぐに応用できる手法である。おた，現在 まで得られた知識を知識工学の手法を用いて記述する ことにより新たなる発見も得られるかもしれない。複雑 多岐にわたる材料と環境の組合せからなる腐食現象の研 究には今後種々の応用が考光られるであるう。

ここではデータベースの一般について触れ，NACE の Corrosion/86, 88 で発表された論文を中心に腐食防食関 連のデータベース，エキスパートシステムを概観する。

\section{2. ファクトデータベース}

データベースとは一連の情報をその要素に分解し, こ れを多目的に利用でさるように構成したコンピュータ・ ファイルと定義される。種々に分類することが可能であ ろらが, 一例として, 案内型, ファクト型と分類される。 文献検索の際利用する文献データベースのように, 文献 抄録等の二次情報をファイルにした案内型データベース に対して,ファクトデータベースは, 文字, 数值, 画像 に限らず一次情報としての事象をそのままデータベース 化したものである。技術の進歩からデータベースは従来 の入れられるすのを入れるといら時代から，必要なるの 
を入れて使ら新しい世代へ移って来たといら。例えば， 新聞の発行に見られるように，記事はまずュンピュータ に入力され, 編集, 発行された後に全文データベースと して使用に供される。記憶容量の制約は無くなってしま ったのである。電算写植が普及して, 出版される以前に 既に計算機可読な情報ができている場合が多く, 全文情 報をそのままデータベース化しようといらことが一つの 方向となっている。CD-ROM 等にみられる記憶媒体の 発達はオフラインのデータベースも可能であり, 辞書や 地図等の電子出版も始まっている。

ファクトデータベースは数の上では急激に増え, 案内 型データベースを越えるよらになってきたが，その主流 はニュース, 経済, 金融, 信用などのビジネス系データ ベースであるといら。科学技術系では気象関係, 産業統 計関係等が多く, 科学技術研究に直接使用できるデータ ベースは多いとはいえない。科学技術に扣ける種々の物 性データ等を収集する活動は古くから行われてきたし， それらをデータベース化しよらとする動さが大小様々な 規模で行われてきた。その中で広く一般からアクセスで きる大規模なものとして, 昭和 63 年 1 月から JOIS-F オンラインネットワークシステム4) が動き出し, 化合物 辞書 $^{5)}$, 熱物性 ${ }^{8)}$, 質量スペクトル7) 等のデータベース が使えるようになった。さらに, DNA, 金属材料強度 ${ }^{8)}$, 結晶構造, 化学物質法規等のデータベースが公開準備中 であるといら。

小野寺 ${ }^{10)}$ は科学系ファクトデータベース形成上の問題 点として, ビジネス系より需要が限られること以外に次 の 3 点を挙げている。

（1）データ作成の困難性

(1) 収集の困難さ (データ源が散在し, 非体系的)

(2) 加工・評価に専門的知識が必要

（2）データベースシステムの複雑性

個々のファクトデータによりデータ構造が異なる

（3）利用形態の多様性

利用が専門的・個別的なため, 多様で高度なアプリ ケーション機能が求められる

上記のデータベースのように明確な物性值等を対象と したものであっても構築は大変であり，また，不特定多 数の研究者が種々の目的で利用するとなれば検索システ ムの開発が重要となる。多様性を極める材料についても データベースは種々作成されている が，腐食防食の分 野に括いては (1) 項の作成の困難性は更に高いであろ う。しかし，腐食防止を目的とするといらことで目的志 向で整理していけば (3) 項の欠点は消党, 潜在的に多数 の需要が期待されることと相まって, データベース構築 の道は開けるであろら。ファクトデータベースはそれを 利用する知識ベースシステムの開発と連係して構築を進
めなければならない。

\section{1 腐食防食分野のファクトデータベース}

NACE は NBS と共同で腐食データベースの構築を 始めており，85 年 6 月にワークショップを開き11), Corrosion/86, 88 で特別セッションを設けている。また， 腐食に関する莫大な量のデータの蓄積を持ら, 自己の発 行する雑誌論文, 大会予稿, 規格, 委員会報告, 書籍等 3000 件以上についての案内データベースないし検索シ

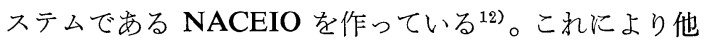
の汎用の文献検索よりも便利に目的とする論文を探すこ とができ，またとのハードコピーを手にすることも可能 であるとしている。さらに検索システムに改良を加光, エキスパートシステム的にしていくとのことである ${ }^{13)}$ 。

一方, 書籍のデータ集として定評のある “Corrosion Data Survey” の金属編，非金属編 2 巻をソフト化し た Cor Sur Vol. 1,2 を発売している。書籍は金属編で 第6版 (1985) を重ねる歴史のあるものであるが, これ をそのままフロッピィディスクに収め, 米国の標準的パ ソコンである IBM PC, XT, AT で自由に検索するこ とができる。縦軸に温度, 横軸に物質の濃度をとったマ トリックスの中に当該材料の腐食速度を記号で表すとい ら，書籍と同じ表現形式を用いているが，データベース の特長として, 特定の温度濃度範囲で, ある腐食速度を 示す材料を直ちに検索する。また, 図を拡大したり, カ ラー化したりすることもあるが, 最大の長所はデータの 一部訂正, 新材料, 新環境の追加等の改訂が容易である こととしている ${ }^{14)}$ 。しかし, 内容的には書籍と変わらな いので, 人によっては值段も半額で一目瞭然の書籍を選 ぶであろら。また，NACE-NBS のデータベース計画で は下記のデータも集めていた ${ }^{15), 16) 。 ~}$

(1) 全面腐食に対する等腐食線図

(2) 米国の大気腐食図

(3) 電位 $-\mathrm{pH}$ 図

(4) 孔食, すきま腐食等の局部腐食

癹表の段階では図の部分的拡大，重畳等ができるだけで あったが, 今後どのような形に発展され, 公開されるの か期待したい。

一方, 西独の DECHEMA では書籍のデータ集では あるが全 12 巻の “Corrosion Handbook” の刊行を開

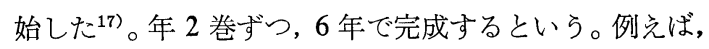
第 1 巻では水蒸気, 塩素, 水酸化カリウム, 塩化アルミ, 酢酸類, 硫酸類, フッ化物類等の物質環境に和ける金属, 非金属，無機材料, 有機材料の挙動が記述され, 原文献 に到達できるよらになっている。

しかし, 腐食研究者にとっては上記のように事実を羅 列したデータ集よりは, 理論に基ついて導き出されたも のの方が安心であろう。材料の熱力学的安定性を熱力学 


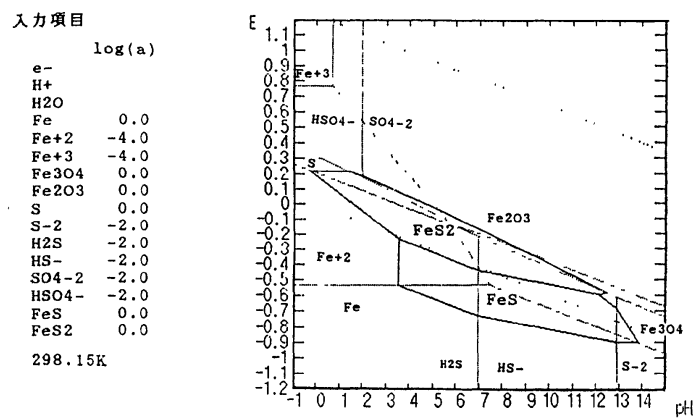

図 $1 \mathrm{Fe}-\mathrm{S}-\mathrm{H}_{2} \mathrm{O}$ 系 $E-\mathrm{pH}$ 図 ${ }^{18)}$

的物性值から導き出すことは Pourbaix 以来行われて 来た。電算機が発達後は電算機で電位-pH 図を書くこと も数多く発表された。小玉 ${ }^{18)}$ の製作したシステムはパソ コンレベルで誰でも電位-pH 図や Ellingham 図等の化 学ポテンシャル図を自動作図することを可能にした。図 1 に示すように物質名, 濃度, 温度を与觉れば, システ ム内の熱力学データベースから必要とする值を引いてき て, 計算の上, 図示してくれる。濃度, 温度を自由に指 定できるといらことで応用範囲は広い。腐食速度につい ては物性值から直接といらわけにはいかないが，例克 ば，尾崎ら ${ }^{18)}$ はガルバニック腐食の設計評価システムを 作り, 自ら実験で求めた腐食速度のデータをデータベー ス化して，そのシステムの計算の根拠としている。

例えば, 大沢ら ${ }^{20)}$ は粒界腐食のコンピューターシミュ レーションを精力的に行っているが，シミュレーション と実験結果が一致したら，機構を証明しただけにとどま らずそれを利用したシステムを作ってもらいたい。究極 的には物性值データベースのデータからシミュレーショ ンにより腐食速度を推定できることであるが，そのため には腐食反応のコンピューターシミュレーションがもっ と盛えにならなければならない。

上記のようにアルゴリズムとデータベースを結び付け るのではなく, データを同じ型式でファイル化し，その 多量のデータから帰納的に原理を見い出そうといら試み がある。Rungta ら ${ }^{21)}$ は原子力発電所における応力腐食 割れ，腐食疲労のデータベース EDEACを作って扣り， 膨大な量の実験室データをこのシステムによって整理す ることにより, ASME コードの再評価やメカニズムの 解明ができるとしている。日本材料学会では金属材料応 力腐食割れ・腐食疲労強度データ集を書籍, テープ両方 で出版している。総数 3023 編の公開文献からデータを 収集し、データベース化しており, 各種の利用が考学ら れる。

Shtefez ${ }^{22)}$ は腐食分極曲線のデータバンクを計画して おり, 既に約 3000 の分極曲線を集め, 広く一般にデー タの提供を呼びかけている。
Mikhailov ら ${ }^{23)}$ は大気腐食に関するデータベースを構 築しようとしている。大気腐食の分野では腐食影響因子 と腐食速度の関係について各種の経験式が出されている が，このような式の再評価がデータベースと結び付くこ とによってなされるかもしれない。

一方, B. J. Moniz ら ${ }^{24)}$ は Du Pont 社内に “Rust” 呼ぶシステムを作って括り，100 か所を越えるプラント サイトや実験室で行われる腐食試験のデータを統一的に 収集, 計算, 訂正等を行っている。当協会の腐食防食デ ータベース分科会に执いても委員各社のデータベースの 実状を紹介してもらったが，市販のデータベースソフト を利用して何らかの型でデータベースを構築している。 しかし，案内型に近いデータベースが多かった。比良 $5^{25)}$ は高温水腐食のデータを集めることを目的としたデ ータベースシステムを作った。記憶装置の進歩を反映し て画像データも直接データベース化している。今後, 目 的を限定して集め, 将来エキスパートシステムにも連動 していくことを意識したデータベースが多くなるのであ ろう。

島ら ${ }^{26)}$ は古くから腐食データのデータベース化の試み を行って来た。最近は画像入力やネットワーキングまで 考えたシステムとし ${ }^{27)}$ ，大型計算機を中心とするシステ ムを完成させた。前記の腐食防食デーダベース分科会に おいては島を中心に, 最近普及著しいパソコン上で動く， 腐食防食データ用のデータベースマネージメントシステ ムの作成を試みたが，まだ道半ばである。共通のデータ の入れ物があれば，目的に応じたデータベースを共同で 構築できる道が開かれる上に，共同実験等の結果をつ口 ッピイディスクの形で持ち寄り評洒することも可能とな るであろう。もちろん自分用のデータベース作成にも使 える。しかし，多様性極まる腐食現象を網羅するために どのような仕様にしたら良いのか，規格化することが一 番難しい。NACEやASTM でも種々規格化していこ らとする動き ${ }^{28)}$ があり，それらも参考にしながら作成し て，実際に使ってみる段階にきているのであろら。

\section{3. エキスパートシステム}

近年, 人工知能ないしエキスパートシステムという情 報処理技術が盛んになってきた。コンピュータに人間の 脳と同じ働きをさせようといらことから知能あるいは思 考過程の分析が進み, 知識工学が生まれ, 認知科学が進 歩した。そして, 知識をことさら重視し，それを基に推 論を進める新しいプログラミング技術が発達してきた。 人工知能については既に解説 ${ }^{29), 30)}$ もあり, 詳しく述べる ことはしないが，従来の手続中心型のプログラミングで はデータ操作の制御を行らアルゴリズムにより，構造の しっかりしたデータを効率良く処理していくのに対し 


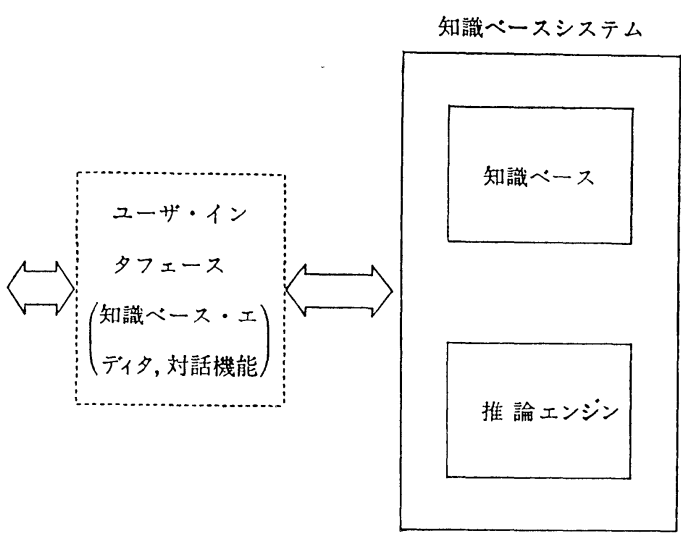

図 2 知識ベース・システムの基本構造

て,この知識型プログラミングでは知識を宣言的に表現 し,独立して取り扱い, 知識工学汇基づく原理により推論 させる。図 2 にあるように推論部は個々の知識とは独立 であり，大部分汎用のものを使用できる。推論の方法に は一定の法則があり，例えばプロダクション・システム では知識をIF (A) THEN (B) のルールで表現して拉き, A が正しければ B であるとする前向き推論と逆の後向 き推論を組み合わせて結論に達する。また，フレームシ ステムでは知識をツリ一構造で表現して扣き，判断させ る。人工知能に向くと言われる LISP, PROLOG 等の 言語は以前から存在したが, 最近, 知識を出入れするエデ ィタと一種ないし数種の推論システムを持った推論エン ジンを組久合わせた，エキスパートシステム開発用の沉 用ッール (シェル)が多く開発され, 利用者は自己の持つ 知識だけを入れることによりシステムが組めることとな った。各種の知識モジュールの逐次追加, 修正が容易に でき,システムを段階的に成長させ, 頭を良くしていくこ とも可能であり，極めて柔軟性に富んでいる。ハードの 面でも, 大容量と高速のマシンを必要とすることから， ワークステーションクラスで考光られてきたが，パソコ ンのレベルも向上し，また逆に第 5 世代コンピュータプ ロジェクトから新しい逐次形推論マシンも生まれてくる 等, 構築上の制約は大小あらゆる規模のシステムに対し て無くなりつつある。

エキスパートシステムは専門家から獲得された専門知 識を利用して推論を行い, 複雑な問題を専門家と同程度 の能力で解決することを目標とするものであるという。 しかし, 機械にとって入れられた各知識間の矛盾は発見 することはできたとしても，知識を入れるのが人間で ある限り，それ以上の創造力を発揮することは不可能で ある。最初の AI システムが化学構造式推定 システム DENDRAL であり，MYCIN 等各種医療診断システム に発展していったように, 解釈, 骖断, 選択, コンサル
タント等の機能は比較的容易にシステムに組みやすい。 腐食分野ではこのような問題が多く，種々のシステム作 りが試みられ始めている。

\section{1 腐食防食分野のエキスパートシステム}

NACE の Corrosion/86, 88 を中心に腐食防食関係の エキスパートシステムを概観してみる。まず関連のシス テムを一覧表にすると表1のようになる。参考のため身 近にある日本の例も 3 例加光てある。

英国の Harwell 原子力研究所と NPL は共同で局部腐 食を中心とする腐食のコンサルタントシステムACHILLES ${ }^{31)}$ を製作した。腐食については素人である技術者 を対象として和り, 予測, 診断, 教育を目的とする大規 模なものである。推論のためのルールベースを持つほか に, データベースを持って和り, 種々の事象の解説, 関 連する代表的な公開文献, 数值データ, 規格, その他の 必要な情報が入って抢り，インフォーメーションシステ ムとなっている。ユーザーの求めに応じて,ルールと推 論エンジンにより，該当する情報が引き出されるわけで ある。腐食分野のようにデータが多様である場合には, 多様なままデータベース化し，検索にエキスパートシス テムを使らことは非常に有効であるらと考觉られる。

ベルギーの Leuven 大学でも大規模なシステムの開発 を目指している。EC には ESPRIT 計画という情報産業 育成計画があり, 1984 年からの 10 年間を第 1 期として 15 億ドル以上の巨費を投じる予定であるという。その 一環として腐食分野では Leuven大学が担当し, $\mathrm{ESCORT}^{33)}$ と名付けるシステムを作りつつある。材料 選択, 防食法, 腐食診断とその対策, オンラインの情報 センターを目指す大規模なエキスパートシステムであ り, その一部の材料選択の部分を Prime ${ }^{34)}$ と名付け, 200 万米ドルの予算と 30 人年のマンパワーで構築を始 めている。既に 4000 以上の知識が入り, 88 年 10 月ま でには完成版を公開する予定とのことである。

上記のような大規模なものでなく, 用途を限定した小 さいシステムも試みられて来た。しかし，86 年の段階で は単にエキスパートシステムを作って見たというるのが 多かった。例えば, Schmauch ら ${ }^{35)}$ はパソコンで油井環 境での腐食診断と石油環境で耐久性を持つェラストマー の選択といら2つのシステムを試作した。しかし, 前者 では腐食知識を IF-THEN ルールで書き写すことの困 難さとパソコンの容量不足を感じた。さらに後者では容 量は充分であったが, 知識が不足していた。また, 知識 の欠陷を見い出すことができたという。パソコンの容量 の問題は技術がすぐに解決してくれるであろう。エキス パートシステムを作ることにより, 我々の知識の欠皕が 分かるといら指摘は我々にとって重要である。

Pessall ら ${ }^{37)}$ は電算機の専門家の助けなしで, PWR の 
表 1 腐食防食のエキスパートシステム例

\begin{tabular}{|c|c|c|c|c|c|c|}
\hline \multirow{2}{*}{ 名 } & \multirow{2}{*}{ 機 } & \multirow{2}{*}{ ハードウェア } & \multicolumn{2}{|c|}{ ソフトウェア } & \multirow{2}{*}{ 内 } & \multirow{2}{*}{ 文献 } \\
\hline & & & 語 & $シ エ ル$ & & \\
\hline ACHILES & Harwell, NPL & DEC VAX 11-780 & PROLOG & & $\begin{array}{l}\text { 局部腐食対策全般の腐食コ } \\
\text { ンサルタント }\end{array}$ & (31) \\
\hline MENTOR & Harwell & & & & $\begin{array}{l}\text { 海水腐食に対する材料選択, } \\
\text { コンサルタント }\end{array}$ & (32) \\
\hline ESCORT & Leuven 大学 & & & & $\begin{array}{l}\text { 大規模な腐食情報システム } \\
\text { のプロトタイプ }\end{array}$ & (33) \\
\hline \multirow[t]{4}{*}{ PRIME } & Leuven 大学 & $\begin{array}{l}\text { SUN } \\
\text { (将来は } 386 \text { パソコン) }\end{array}$ & & KEE-3 & $\begin{array}{l}\text { 材料選択 } \\
\text { ESCORT の一部分 }\end{array}$ & (34) \\
\hline & Conoco Inc. & IBM PC & FORTH & EXPERT-3 & $\begin{array}{l}\text { 油井環境での腐食損傷解析 } \\
\text { 耐油性エラストマーの選択 }\end{array}$ & (35) \\
\hline & Cabot Co. & IBM PC & & Expert Ease & $\begin{array}{l}\text { パルプ・製紙業におけける腐 } \\
\text { 食診断及び材料選択 }\end{array}$ & (36) \\
\hline & Westinghouse & & LISP 方言 & $\begin{array}{l}\text { Personal Con- } \\
\text { sultant }\end{array}$ & $\begin{array}{l}\text { PWR の配管と支持板の材 } \\
\text { 料選択 }\end{array}$ & $(37)$ \\
\hline DURCON & NBS & IBM PC & PASCAL & & 耐久コンクリートの診断 & (38) \\
\hline CPI & Corrpro Co. & & Turbo Prolog & & $\begin{array}{l}\text { カソード防食システムの設 } \\
\text { 計 }\end{array}$ & (39) \\
\hline \multirow[t]{3}{*}{ COREX } & Battelle & XEROX 1121 & & CSRL & $\begin{array}{l}\text { 石炭火力の廃煙脱硫装置の } \\
\text { 腐食診断, 対策, 材料選択 }\end{array}$ & $(40)$ \\
\hline & U.S. Army CERL & & KRL, Prolog & ESP Advisor & 材料選択 & $(41)$ \\
\hline & $\begin{array}{l}\text { フィンランド技術 } \\
\text { 研究センター }\end{array}$ & $\mathrm{PC}$ & PASCAL & INSIGHT $2_{+}$ & $\begin{array}{l}\text { 予測, 損傷解析, 材料選定 } \\
\text { 等のプロトタイプ }\end{array}$ & $(42)$ \\
\hline COREXYS & Ontario Hydro & & & EXSYS & $\begin{array}{l}\text { 発電所のボイラー管の腐食 } \\
\text { 診断 }\end{array}$ & $(43)$ \\
\hline \multirow[t]{5}{*}{ MOR or LES } & $\begin{array}{l}\begin{array}{l}\text { Sun Refining \& } \\
\text { Marketing }\end{array} \\
\end{array}$ & DEC & FORTRAN & OPS 5 & $\begin{array}{l}\text { 製油所のオンラインでの腐 } \\
\text { 食問題のアドバイス }\end{array}$ & (44) \\
\hline & $\begin{array}{l}\text { E.I. du Pont de } \\
\text { Nemours \& Co. }\end{array}$ & IBM PC & & INSIGHT $2_{+}$ & ボイラーの水処理の補助 & (45) \\
\hline & IHI & & FORTRAN & OPS 5 & $\begin{array}{l}\text { 原子力発電所配管の欠陌評 } \\
\text { 価 }\end{array}$ & (46) \\
\hline & $\begin{array}{l}\text { 中部電力, 東洋工 } \\
\text { ンジニアリング }\end{array}$ & & & OPS-83 & 電力用復水器の腐食診断 & (47) \\
\hline & $\begin{array}{l}\text { 大阪府立産業技術 } \\
\text { 総合研究所 }\end{array}$ & NEC PC 9801 & $\mathrm{C}$ & 創 玄 & $\begin{array}{l}\text { 一般的な腐食骖断のプロト } \\
\text { タイプ }\end{array}$ & (48) \\
\hline
\end{tabular}

配管と支持板の材料選択システムを構築し，実際に各種 合金の組合せの適否をシステムに判断させている。そし て，エキスパートシステムを作ることにより，その専門 家がいらなくなるのではなく, システムを改良するため に必要であり, システムは知識の継承, 伝播, 教育に役 立つばかりでなく，専門家を同じ仕事の繰返しから解放 し，知識が公開の場に出されることにより，誤りも見い 出しやすくなる等の長所を指摘している。
2 年後の 88 年になると数が増えたばかりでなく, 内 容も変化を見せている。例党ば，開発するシステムに合 わせてプログラミングッールを選んでいる。Nicholas ${ }^{39)}$ はカソード防食の CAD システムを目指して抒り，100 程度のルールを持つプロトタイプを作り，教育には役に 立つとしているが，カソード防食では計算等が多いた め, 既成のシェルより, Turbo Prolog のような言語を 直接用いた方が良いとしている。Eugene ら ${ }^{48)}$ が指摘し 
ているように，防食技術とりわけカソード防食について はパソコンの応用できる場面が多い。土壤抵抗, 迷走電 流等の現場データ, 価格積算等の経済分析, 最近進歩の 著しい電位分布のシミュレーションを考虑した設計等モ ジュール化できそらなシステムが多い。これらのモジュ ールをすべて包含した実用に耐光るカソード防食のコン ピュータ支援設計システムの完成を待ちたい。

Koch ら ${ }^{40)}$ は自研究所で開発した分類型エキスパート システム構築支援ツール CSRL が特に診断, 選択シス テムの構築に適するとして, 手持ちのデータで廃煙脱硫 装置の腐食診断, 対策, 材料選定システムを作ってみせ た。同じ手法を用いれば容易にシステムが組めるとして いる。

Kumar ら ${ }^{41)}$ も構築の容易さを考慮して 2 種類の言語 を使觉るシェル ESP Advisor を選んでいる。

もら一つ言光ることは既に手法が成熟した技術につい てェキスパートシステムを作り，実用に供していること である。Mayer ${ }^{43)}$ は発電所のボイラー管の損傷機構を 判断するシステムを既存の EPRI のマニュアルに沿う 形で構築している。伏見ら ${ }^{47)}$ の復水器の腐食診断も既飞 解決した問題であるという。しかしシステムを組んでみ ると表記法が難しく,ルール数は 400 に達した。また, この 2 つのステムは共に錆などの実際の写真をシステ ムに組みこんでいる。教育的要素を入れるとなると実例 を持ってくることが一番速いのであろう。

Loushin $^{44)}$ は製油所のコンピュータシステムの中にシ ステムを組み込み，操作パネル上の CRT 亿直接腐食の アドバイスが出るようにした。コンピュータシステムが FORTRAN で動いているためOPS 5 をFORTRAN と 翻訳しているといら。

Westcott ら ${ }^{50}$ は Harwell でシステム開発してきた経 験から腐食の情報システムについて忠告を述べている。 その中で構築について，ヒューリスティク（専門家の多 少確実さには欠けるがうまいやり方といった経験的）な 知識が扱えるため腐食にとって有利であること，知識べ 一スと他のテキスト的データ, 数值データ, 数式モデル 等を関係付けるソフトを使らべきことなぞ，このシステ ムの柔軟性を支持することを述べている。

実用化されてきたといっても専門家ととって目新しい 事実がでてくるわけではなく, 知識の整理とシステム構 築の面倒臭さに比べれば得るものが少ないことも事実で あろら。エキスパートシステムは KE (Knowledge Engineer) が専門家から知識を獲得して組み立てるもの とされている。しかし，とれでは知識のレベルが $\mathrm{KE}$ の理解した水準をで下がってしまう。とれよりも自分で 自分の専門の分野について作ってみたらどらだろう。事 実, 電算機の専門家の助けなしに作ったとする人々 ${ }^{37), 42)}$
もいる。アルゴリズムを組み立てるより，素人にとって はとっつきやすそらである。シェルも改善されてきた し，パソコン上でもできるよらになってきた。システム を組み立てて見れば，ぞの知識が足らないか問題点が明 確になるであるう。

アルゴリズムを用いてシミュレーションによる攻め, 知識工学的な攻め, 数々の小さいモジュールが確立して いけばやがて大きな問題も解決していくであろう。ま た, 知識工学的手法が発達し, 予測, 設計等の創造性の 高い仕事, 類推, 㷌納などコンピュータの苦手な推論が できるようになり，研究手段として使えるようになるこ とも期待したい。

\section{4.おわりに}

腐食に上る金属材料の損失が莫大であり，それは防食 知識の普及によりかなり防げること。そのために腐食デ 一タベースの構築が有効な手段であること。腐食関連の ファクトデータベース，エキスパートシステムの現状を 概観し、コンピュータを使ったシミュレーション, 知識 工学的手法による知識の整理が, 新たな知識の獲得や知 識の普及に役立ちそらなことを述べた。この方面への努 力は研究者にとってはもら一つ気乗りがしないかもしれ ないが，これからの情報化時代にこのような形での整理 はますます必要となるであろらし，払った努力は報われ るであらうと信ずる。（1988 年 8 月 2 日受理)

\section{文献}

1）腐食損失調査委員会：防食技術，26，401 (1977).

2）科学技術庁資源調查所編：「身近汇あるさびとそ の対策」, p. 36, 大藏省印刷局 (1986).

3) L. H. Bennett, J. Kruger, R. L. Parker, E. Passaglia, C. Reimann, A. W. Ruff \& H. Yakowitz: NBS SP 511-1 (1978).

4）黑澤慎治：情報管理, 31, 15 (1988).

5）荒木啓介：情報管理, 31, 21 (1988).

6）志村和樹, 阿部篤史：情報管理, 31, 41 (1988).

7) 岡野恵子, 阿部篤史：情報管理, 31, 56 (1988).

8) 西島 敏：日本機械学会誌, 90, 1296 (1987).

9）例光ば，岩田修一：日本機峨学会誌， 89, 1335 (1986).

10）小野寺夏生：第 3 回腐食防食データベース分科 会資料, (1986).

11) E.D. Verink, J. Kolts, J. Rumble \& G. M. Ugiansky: Mater. Perform., 26 [4] 55 (1987).

12) N. E. Hamner: Corrosion/86, Paper No. 41, NACE (1986).

13) N. E. Hamner: Corrosion/88, Paper No. 122 , NACE (1988).

14) D. E. Clausen: Corrosion/86, Paper No. 43, NACE (1986).

15) D. C. Clausen, G. M. Ugiansky \& A. C. Van Orden: "4th Asian-Pacific Corrosion Control 
Conference" Vol. 2, p. 1258, Tokyo (1985).

16) G. M. Ugiansky, A. C. Van Orden \& D.E. Clausen: Corrosion/86, Paper No. 39, NACE (1986).

17) DECHEMA: "Corrosion Handbook" Vol. 1, VCH Verlag. (1987); Vol. 2 (1988).

18）小玉俊明：腐食防食' 88 講演集, p. 42, 腐食防食 協会 (1988).

19）尾崎敏範, 石川雄一, 魏山雅男: 腐食防食 ' 85 , p. 287，腐食防食協会 (1985).

20）大沢基明，池津福治郎：防食技術, 34, 331 (1985); 腐食防食 '87, p. 231 (1987); 腐食防食 '88, p. 50 (1988).

21) R. Rungta, H. Mindlin \& J. D. Gilman: Corrosion/86 Paper No. 42, NACE (1986); Mater. Perform., 25 [11] 43 (1986).

22) R. Shtefez: Zashch. Met., 23, 180 (1987).

23) A. A. Mikhailov, M. N. Suloyeva \& Yu. N. Mikhailovski: Zashch. Met., 24, 355 (1988).

24) B. J. Moniz \& T. C. Wool: Corrosion/86, Paper No. 40, NACE (1986).

25）比良康夫, 本田 卓: 腐食防食 ' 88 講演集, p. 54, 腐食防食協会 (1988).

26）島 貢, 北村義治，鈴木紹夫：防食技術， 30, 91 (1981).

27）島 貢，北村義治，鈴木紹夫：防食技術，36， 481 (1987).

28) D. B. Anderson: Corrosion/88, Paper No. 119, NACE (1988).

29）柴田啓一，篠ヶ谷達司：防食技術, 37, 42 (1988).

30) W. Fischer, L. Fohmann \& W. Mader: Werk. u. Korr., 38, 375 (1987).

31) C. Westcott, D. E. Williams, I. F. Croall, S. Patel \& J. A. Bernie: Corrosion/86, Paper No. 54, NACE (1986).

32) J. N. Wanklyn \& N. J. M. Wilkins: Br. Corros. $J .$, 20, 161 (1985).

33) W. F. Bogaerts, M. Rijckaert \& C. Bettendorf: Corrosion/86, Paper No. 58 NACE (1986).
34) M. J. S. Vancoille, W. F. Bogaets \& M. J. Rijckaert: Corrosion/88, Paper No. 121 NACE (1988).

35) E. H. Schmauch \& W. H. Thomason: Corrosion/86, Paper No. 55, NACE (1986).

36) S. E. Marschand, D. C. Carlson \& A. I. Asphahani: Corrosion/86, Paper No. 56 NACE (1986)

37) N. Pessall \& J. Schreurs: Corrosion/86, Paper No. 57, NACE (1986).

38) J. R. Clifton: Corrosion/86, Paper No. 60, NACE (1986).

39) K. W. Nicholas: Corrosion/88, Paper No. 96, NACE (1988).

40) G. H. Koch \& S. C. Rinehart: Corrosion/88, Paper No. 123, NACE (1988).

41) A. Kumar, A. Odeh \& T. Wiersema: Corrosion/88, Paper No. 125, NACE (1988).

42) T. Hakkarainen, L. I. Carpén \& R.-L. Tuulikki Hakkarainen: Corrosion/88, Paper No. 126, NACE (1988).

43) P. Mayer: Corrosion/88, Paper No. 127, NACE (1988).

44) L. L. Loushin: Corrosion/88, Paper No. 164, NACE (1988).

45) R. A. Leathrum: Corrosion/88, Paper No. 201, NACE (1988).

46）片岡茂樹, 岡本旦夫：腐食防食'87 講演集, p. 223，腐食防食協会 (1987).

47) 伏見富和, 恩田勝弘, 柴田啓一, 松本桂一, 篠ヶ 谷達司：腐食防食' 88 講演集, p. 58 , 腐食防食協 会 (1988).

48）袖岡孝好，佐藤幸弘，吉田総夫：防錆管理， 32, 48 (1988).

49) E. A. DeCarlo, J. Wagner, Jr. \& D. M. Waters: Corrosion/88, Paper No. 112, NACE (1988).

50) C. Westcott \& J. N. Wanklyn: Corrosion/88, Paper No. 128, NACE (1988). 